\title{
PENGARUH IDENTITAS GLOBAL, NILAI KEUNTUNGAN DAN NIAT BELI KAIN TENUN NTT
}

\author{
Wendelinus Retas Daeng
}

\author{
Program Studi Manajemen, STIE Indonesia Banking School
}

Wendydaeng@gmail.com

\begin{abstract}
The factors that determine a person to buy lkat Flores- NTT woven fabrics are global identity, perceived functional value, perceived individual value, perceived social value and purchase intention. Flores lkat Tenun- NTT is one of the woven fabrics that is popular with tourists when visiting the Flores area to be used as souvenirs. Therefore, the researcher wanted to find out whether global identity, perceived functional value, perceived individual value, and perceived social value can have an implication for purchase intention in Flores ikat fabric products. The quantitative method is the method used in conducting the analysis of this research, as well as collecting data by distributing questionnaires to 140 respondents consisting of men/women who have an age range of 23-39 years, have the intention to buy Flores ikat cloth products, and are tourists who come from Jabodetabek. In this study, researchers used the structural equation model (SEM) method with the help LISREL version 8.8. The results of this study prove that there is a positive relationship between global identity and perceived functional value on purchase intention. In this study it was also found that perceived individual value and perceived social value had no effect on purchase intention.
\end{abstract}

Keywords: woven fabrics, kain tenun ikat, global identity, purchase intention

\section{PENDAHULUAN}

Di zaman sekarang ini dimana pariwisata menjadi salah satu subjek yang menarik untuk di-explore, semua daerah di Indonesia berlomba-lomba meningkatkan dan mengembangkan potensi wisata yang dimiliki demi menarik peminat wisatawan baik lokal, nasional, maupun mancanegara, tak terkecuali Provinsi NTT. Satu dari beberapa hal yang menjadi daya tarik wisata NTT yaitu warisan budaya berupa kain tenun ikat. Menurut Menteri Pariwisata Indonesia, Arief Yahya, tenun ikat merupakan sarana promosi potensi wisata yang dapat meningkatkan "nilai jual" NTT.

Produk tenun ini ternyata lebih banyak digemari daripada tenun daerah lainnya dikarenakan motif dan corak unik yang menonjolkan kesan etnik daerah asalnya. 
Adalah hal yang lumrah jika tenun ikat menjadi sasaran para wisatawan ketika berwisata ke NTT.

Kerajinan khas daerah dan pariwisata merupakan dua hal yang menujukan hubungan resiprokal (Amir, 2018). Artinya, kerajinan menjadi magnet wisata sehingga pariwisata bertumbuh dan secara tidak langsung berpengaruh terhadap peningkatan kualitas kerajinan tersebut. Tidak terkecuali tenun ikat yang merupakan kerajinan yang menjadi incaran wisatawan karena corak/motif kain yang unik yang menunjukan kekhasan budaya daerah. Dalam hal ini intensi wisatawan untuk membeli kain tenun menjadi hal yang menarik untuk dikaji.

Diambil dari data Badan Ekonomi Kreatif Bekraf (2016), ekonomi kreatif di Indonesia bertumbuh dan dipengaruhi paling banyak oleh tiga subsektor, yaitu culinary, fashion, dan kriya. Seperti tertera pada gambar 1 data perkembangan PDB ekonomi kreatif di Indonesia yakni:

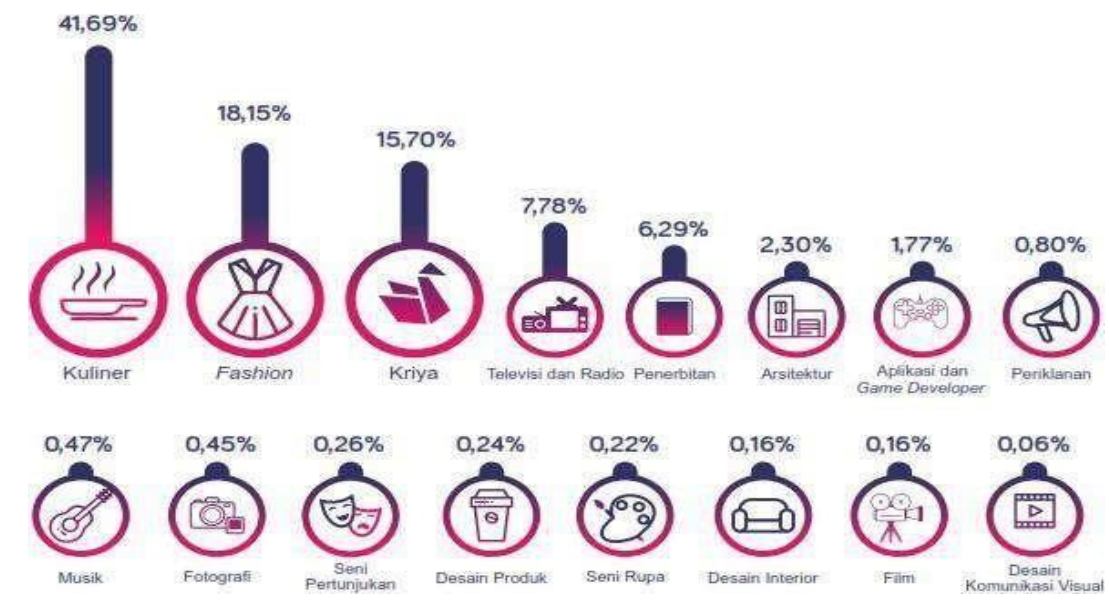

Gambar 1. Informasi pertambahan PDB EKRAF di Indonesia

Gambar 1 menunjukan perkembangan subsektor industri kriya sebagai salah satu sektor ekonomi kreatif yang mendominasi ekonomi Indonesia. Berdasarkan data peninjauan Badan Ekonomi Kreatif (Bekraf) 2016 merilis bahwa pertumbuhan PDB dari subsektor kriya menyumbang $15,7 \%$ pada pertumbuhan ekonomi nasional di tahun 2016. Hal ini menunjukkan bahwa ketertarikan masyarakat Indonesia terhadap seni kerajinan tangan merupakan hal yang lazim.

Selain itu, terlepas dari hakikat kain tenun ikat sebagai objek kriya/kerajinan tangan dan kesenian, menurut Tiarma Sirait, seorang Fashion Art Desainer, seni dan fashion punya keterkaitan yang sangat erat yang mempengaruhi trend fashion itu sendiri. Fashion menjadi bagian yang tidak dapat dilepaskan dari cara 
berpenampilan dan gaya hidup keseharian. Dengan begitu, fashion juga merupakan bentuk refleksi dari status sosial.

Minat konsumen untuk membeli kain tenun dapat terlihat dari semakin banyak animo masyarakat terhadap kain tenun yang didukung oleh perkembangan trend fashion dan adanya berbagai festifal kain tenun oleh fashion designer terkenal yang mengusung tema tenun ikat di setiap event mereka (baik event nasional maupun mancanegara). Sehingga tidak mengherankan apabila kain tenun ikat sudah menjadi identitas budaya Indonesia di era globalisasi ini, dan menjadi trend fashion yang diminati masyarakat global, khususnya masyarakat "kalangan atas/elit". Identitas kain tenun dalam masyarakat global pun menjadi daya tarik tersendiri dalam penelitian ini, karena berimplikasi pada minat pembelian masyarakat global.

Identitas global didefinisikan sebagai bentuk kecendrungan konsumen dalam interaksinya dengan kebudayaan global (Gao et al. 2017). Hal ini didukung pula oleh Lingjiang Tu et al. (2012) dalam penelitiannya mengemukakan bahwa identitas global berhubungan dengan identitas konsumen sebagai bagian dari eksistensi masyarakat global sehingga berpengaruh terhadap adopsi trend/gaya hidup global.

Menurut Heine, K. (2017), suatu barang dikatakan mewah apabila setidaknya memiliki karakateristik superior dalam hal rarity, price, aesthetics dan quality. Konsumen dengan identitas global yang tinggi tentunya menunjukan mnat yang tinggi pula terhadap kepemilikan barang mewah.

Sehubungan dengan hal ini, value suatu produk menjadi jembatan yang menghubungkan identitas global yang dimiliki konsumen dengan keputusan untuk membeli suatu produk. Value suatu produk yang dimaksud dalam penelitian ini merujuk pada perceived value yang dibangun oleh konsumen dan mempengaruhi product purchase intention. Walsh et al. (2014) menyatakan perceived value dapat ditinjau dari 4 aspek yaitu performance value (merujuk pada manfaat dan kualitas produk, realibility, serta durability), value for money (merujuk pada biaya yang dikeluarkan untuk mendapatkan suatu produk jika dibandingkan dengan umur ekonomis yang dimilikinya), emotional value (merujuk pada motif pribadi untuk membeli suatu produk), dan social value (merujuk pada status sosial atau anggapan sosial yang muncul ketika memiliki sutu produk)

Pada penelitian ini, peneliti berfokus pada bagaimana perceived functional value, perceived individual value, perceived social value memjembatani keinginan konsumen dengan identitas global yang tinggi untuk membeli suatu produk yang terbilang "mewah". Menurut Hennigs et al. (2012), perceived functional value menggambarkan nilai produk yang timbul sebagai akibat dari persepsi konsumen 
terhadap kegunaan dan keunikan produk. Dalam hal ini, konsumen dengan identitas global yang tinggi akan lebih konservatif dan rasional dalam membeli produk mewah.

\section{KAJIAN PUSTAKA}

\subsection{Model Penelitian}

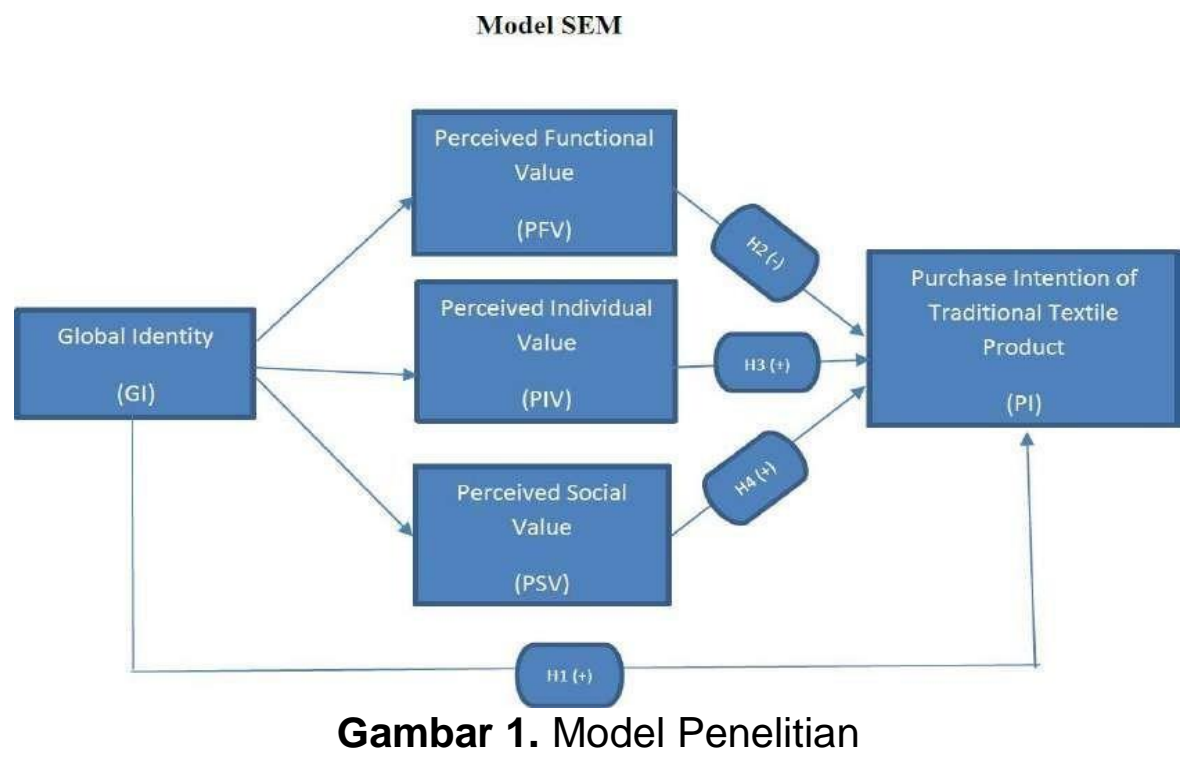

\subsection{Global identity terhadap purchase intention of luxury product}

Dubois et al. (2005) dalam penelitiannya pun mengatakan customer yang dipengaruhi oleh budaya multicultural memiliki persepsi yang berbeda terhadap barang mewah. la pun menambahkan adanya perbedaan persepsi antara customer dengan pengaruh budaya lokal/ global yang tinggi dan customer dengan pengaruh budaya lokal/global yang rendah. Beberapa peneliti terdahulu menemukan bahwa keinginan membeli barang mewah merefleksikan identitas customer (Berger and Heath, 2007; Guzmán and Paswan, 2009; Reed et al., 2012). Dimana hal tersebut terkait dengan nilai-nilai yang dianut, termasuk global consumer culture (Steenkamp, 2010) dan global human values (Torelli et al. 2012). Lebih jauh lagi, Strizhakova (2015) menambahkan customer dengan identitas global yang tinggi akan memiliki intensi yang lebih tinggi untuk membeli barang mewah dibandingkan barang lokal. Hal ini didasarkan pada fakta bahwa konsumen dengan identitas global yang tinggi memliki wawasan/ pengetahuan yang lebih terkait global market dan barang mewah. Berdasarkan teori ini, hipotesis yang digunakan adalah

H1: Global identity memiliki pengaruh positif terhadap purchase intention of luxury product 


\subsection{Perceived functional value terhadap purchase intension of consumer with global identity}

Barang mewah melekat pada image kualitas yang superior yang mengkomunikasikan nilai intrinsic yang lebih dibandiingkan produk lainnya (Bian and Forsythe, 2012). Kualitas produk yang seperti itu merupakan faktor pendorong utama pembelian barang mewah (Park and Park, 2003). Zhang and Cude (2018) dalam penelitiannya juga menambahkan kualitas merupakan faktor yang memiliki pengaruh significant terhadap pembelian barang mewah. Namun secara implemetasi, customer dengan identitas global yang tinggi cenderung lebih menghargai adanya kesamaan nilai di antara kemajemukan, sehingga mereka tidak mempedulikan nilai fungsional ketika membeli barang mewah (Hennigs et al. 2012). Berdasarkan teori ini, hipotesis yang digunakan adalah:

$\mathrm{H} 2$ : Perceived functional value memiliki pengaruh negatif terhadap purchase intension of consumer with global identity.

\subsection{Perceived individual value terhadap purchase intension of consumer with global identity}

Perceived Individual Value menggambarkan bahwa nilai yang dipersepsikan konsumen berasal atau timbul dari perasaaan kebahagiaan, kenikmatan, dan kesuksesan ketika menggunakan produk tertentu (Hennigs et al. 2012). Nilai-nilai emosional dan afektif, seperti keindahan estetika dan kegembiraan, adalah nilai-nilai penting dari produk-produk mewah. Dari perspektif ini, konsumen yang membeli produk-produk mewah mungkin mendapatkan pengalaman yang tidak menyenangkan atau beberapa pemenuhan pribadi lainnya (Sheth et al. 1991). Konsumen dengan identitas global yang tinggi dapat semakin memperkuat karakteristik ini dengan membeli produk mewah untuk asosiasi simbolis mereka dalam komunitas global, selain untuk tujuan hedonism dan rasional (Vigneron dan Johnson, 2004). Oleh karena itu, kami mengusulkan bahwa nilai individual yang dipersepsikan dari produk-produk mewah memediasi secara positif hubungan antara globali identity dan niat beli barang mewah.

H3: Perceived individual value memiliki pengaruh positif terhadap purchase intension of consumer with global identity.

\subsection{Perceived social value terhadap purchase intention of consumer with global identity}

Banyak studi psikologi dan pemasaran telah menunjukkan bahwa konsumen dipengaruhi oleh kelompok sosial referensi mereka ketika membuat keputusan pembelian (Bearden et al. 1989). Selain itu, karena produk-produk mewah sering mencakup reputasi global, pengakuan global dan kesadaran sosial di seluruh dunia, konsumen yang berorientasi global membeli produk- produk mewah untuk mendapatkan pengakuan global (Dittmar, 1994) dan membentuk keanggotaan 
dalam komunitas global. Oleh karena itu, kami mengusulkan bahwa nilai sosial yang dipersepsikan dari produk-produk mewah secara positif memediasi hubungan antara identitas global dan minat pembelian.

H4: Perceived social value memiliki pengaruh positif terhadap purchase intension of consumer with global identity

\section{METODOLOGI PENELITIAN}

Sampel dalam penelitian ini adalah sejumlah konsumen generasi muda milenial yang memiliki ketertarikan terhadap kain tenun ikat Flores-NTT. Jumlah sampel dalam penelitian ini sebagai berikut: Jumlah sampel $=28 \times 7=196$

Data digunakan melalui online survey Google Form dengan jumlah sampel yang diambil dalam penelitian ini adalah 125 responden, dengan kriteria Usia Generasi Milenial 23-39 tahun, Kriteria yang menyukai mengoleksi barang mewah (dalam hal ini kain tenun ikat Flores- NTT sebagai objek penelitian).

Tabel 1. Operasional Variabel

\begin{tabular}{|c|c|c|c|}
\hline Nama Variabel & Definisi Variabel & Alat Pengukur & $\begin{array}{c}\text { Skala } \\
\text { Pengukuran }\end{array}$ \\
\hline Global Identity & $\begin{array}{l}\text { didefenisikan } \\
\text { sebagai minat } \\
\text { konsumen terhadap } \\
\text { budaya global dan } \\
\text { identifikasi dengan } \\
\text { orang- orang di } \\
\text { seluruh dunia } \\
\text { (Gao et al., 2017) }\end{array}$ & $\begin{array}{l}\text { Gl1:Saya merasa seperti hidup di } \\
\text { desa global } \\
\text { Gl2: Saya merasa apa yang saya } \\
\text { lakukan dapat menyentuh } \\
\text { seseorang di seluruh dunia GI3: } \\
\text { Saya merasa seperti "tetangga } \\
\text { sebelah" dengan orang-orang yang } \\
\text { tinggal di belahan dunia lain } \\
\text { Gl4: Saya merasa bahwa saya } \\
\text { memiliki hubungan keluarga dengan } \\
\text { semua orang di dunia seolah-olah } \\
\text { mereka adalah keluarga saya. } \\
\text { Gl5:Saya merasa bahwa orang- } \\
\text { orang di seluruh dunia lebih mirip } \\
\text { daripada Value of Luxury yang } \\
\text { berbeda (Hennigsetal., 2012). }\end{array}$ & Likert \\
\hline Functional Value & $\begin{array}{l}\text { mengacu pada } \\
\text { manfaat inti dan } \\
\text { utilitas dasar produk } \\
\text { termasuk kualitas, } \\
\text { fungsionalitas, } \\
\text { keunikan, kegunaan, } \\
\text { keandalan, dan } \\
\text { daya tahan (Sheth } \\
\text { et al., 1991). }\end{array}$ & $\begin{array}{l}\text { FV1: Kualitas produk yang unggul } \\
\text { adalah alasan utama saya untuk } \\
\text { membeli produk mewah. } \\
\text { FV2: Saya mengutamakan kualitas } \\
\text { daripada prestise ketika } \\
\text { mempertimbangkan pembelian } \\
\text { produk mewah } \\
\text { FV3: Saya cenderung mengevaluasi } \\
\text { atribut Substantif dan kinerja produk } \\
\text { mewah daripada mendengarkan } \\
\text { pendapat orang lain }\end{array}$ & Likert \\
\hline
\end{tabular}

Bersambung... 
Lanjutan Tabel 1...

\begin{tabular}{|c|c|c|c|}
\hline & & $\begin{array}{l}\text { FV4: Produk mewah yang disukai } \\
\text { banyak orang tetapi tidak } \\
\text { memenuhi standar kualitas saya } \\
\text { tidak akan pernah masuk dalam } \\
\text { pertimbangan pembelian saya }\end{array}$ & Likert \\
\hline Individual Value & $\begin{array}{l}\text { mengacu pada } \\
\text { kepuasan diri, } \\
\text { kesenangan } \\
\text { pribadi, dan nilai- } \\
\text { nilai yang baik dari } \\
\text { produk- produk } \\
\text { cairan. } \\
\text { Karena produk } \\
\text { mewah dapat } \\
\text { menandakan } \\
\text { estetika global dan } \\
\text { hedonisme, } \\
\text { konsumen yang } \\
\text { mencari identitas } \\
\text { global memiliki } \\
\text { kecenderungan } \\
\text { untuk membeli } \\
\text { barang- barang } \\
\text { mewah untuk } \\
\text { mengikuti gaya } \\
\text { hidup yang } \\
\text { menyenangkan. }\end{array}$ & $\begin{array}{l}\text { IV1: Saya mendapatkan kepuasan diri } \\
\text { dari membeli produk mewah } \\
\text { IV2: Membeli pakaian mewah } \\
\text { membuat saya merasa baik } \\
\text { IV3: Mengenakan pakaian mewah } \\
\text { memberi saya banyak kesenangan } \\
\text { IV4: Ketika saya berada dalam } \\
\text { suasana buruk, saya dapat membeli } \\
\text { produk- produk mewah sebagai hadiah } \\
\text { untuk diri sendiri untuk meringankan } \\
\text { beban emosional saya } \\
\text { IV5: Saya memandang produk merek } \\
\text { mewah sebagai hadiah untuk diri saya } \\
\text { sendiri untuk merayakan sesuatu yang } \\
\text { saya lakukan dan merasa senang } \\
\text { IV6: Saya memandang pembelian } \\
\text { produk mewah sebagai hadiah untuk } \\
\text { diri saya sendiri untuk merayakan } \\
\text { kesempatan yang saya yakini penting } \\
\text { bagi saya } \\
\text { IV7: Secara keseseluruhan, saya } \\
\text { membeli Kain Tenun Ikat Flores } \\
\text { sebagai hadiah untuk menyenangkan } \\
\text { diri saya }\end{array}$ & Likert \\
\hline Social Value & $\begin{array}{l}\text { adalah manfaat } \\
\text { utilitas yang } \\
\text { dirasakan } \\
\text { konsumen dari } \\
\text { yang diakui dalam } \\
\text { kelompok sosial } \\
\text { mereka, atau } \\
\text { terkesan oleh } \\
\text { orang lain } \\
\text { (Wiedmann et al., } \\
\text { 2009; Vigneron } \\
\text { dan Johnson, } \\
\text { 2004) }\end{array}$ & $\begin{array}{l}\text { SV1: Saya ingin tahu produk } \\
\text { mewah apa yang memberi kesan } \\
\text { baik pada orang lain } \\
\text { SV2:Bagi saya,persepsi teman } \\
\text { saya tentang berbagai produk } \\
\text { mewah adalah penting. } \\
\text { SV3:Saya memperhatikan jenis } \\
\text { orang apa yang membeli produk } \\
\text { mewah tertentu } \\
\text { SV4: Penting untuk mengetahui } \\
\text { pendapat orang lain tentang orang } \\
\text { yang menggunakan produk mewah } \\
\text { tertentu } \\
\text { SV5: Saya tertarik untuk } \\
\text { menentukan produk mewah apa } \\
\text { yang harus saya beli untuk } \\
\text { membuat kesan yang baik pada } \\
\text { orang lain } \\
\text { SV6: Adalah penting bahwa orang } \\
\text { lain memiliki pendapat yang tinggi } \\
\text { tentang bagaimana saya } \\
\text { berpakaian dan berpenampilan }\end{array}$ & Likert \\
\hline
\end{tabular}




\begin{tabular}{|c|c|c|c|}
\hline & & $\begin{array}{l}\text { SV7: Jika saya membeli sesuatu } \\
\text { yang mahal, saya akan khawatir } \\
\text { tentang apa yang orang lain } \\
\text { pikirkan tentang Saya }\end{array}$ & \\
\hline $\begin{array}{l}\text { Purchase } \\
\text { Intention }\end{array}$ & $\begin{array}{l}\text { adalah (minat) } \\
\text { seseorang dalam } \\
\text { merencanakan } \\
\text { atau bagaimana } \\
\text { seseorang akan } \\
\text { berperilaku dari } \\
\text { siatuasi tertentu } \\
\text { dengan cara-cara } \\
\text { tertentu baik akan } \\
\text { melakukannya } \\
\text { atau tidak Fishbein } \\
\text { dan Ajzen (1975) }\end{array}$ & $\begin{array}{l}\text { PI1: Saya membeli aksesoris } \\
\text { mewah untuk menunjukkan siapa } \\
\text { saya } \\
\text { PI2: Saya akan membeli aksesori } \\
\text { mewah hanya karena itu berstatus } \\
\text { PI3: Memiliki aksesoris mewah } \\
\text { menunjukkan simbol kekayaan } \\
\text { PI4: Saya akan membayar lebih } \\
\text { untuk aksesori mewah jika memiliki } \\
\text { status } \\
\text { PI5: Aksesori mewah penting bagi } \\
\text { saya karena membuat saya merasa } \\
\text { lebih dapat diterima di lingkaran } \\
\text { pekerjaan } \\
\text { Saya }\end{array}$ & Likert \\
\hline
\end{tabular}

Sumber: dari penelitian terdahulu

\section{HASIL DAN PEMBAHASAN}

\subsection{Hasil Analisis Goodness of Fit}

Tabel 2. Godness of Fit

\begin{tabular}{|l|l|l|}
\hline $\begin{array}{l}\text { Ukuran Goodness of Fit } \\
\text { Measurement }\end{array}$ & $\begin{array}{l}\text { Tingkat Kecocokan } \\
\text { YangDapat Diterima }\end{array}$ & Hasil Uji \\
\hline Absolute Fit Measure & Acceptable Fit \\
\hline $\begin{array}{l}|l| \\
\text { RMSEA }\end{array}$ & 0.051 & Acceptable Fit \\
\hline CFI & 0.95 & \\
\hline Persimony Fit Index & \multicolumn{2}{|l|}{ Acceptable Fit } \\
\hline PNFI & 0.77 & \\
\hline
\end{tabular}

Sumber: Pengolahan data penulis (2020)

Pada tabel 2 menunjukkan bahwa seluruh perhitungan telah memenuhi syarat yakni RMSEA $\leq 0.08, \mathrm{CFI} \geq 0.95$, dan PNFI $0 \leq \mathrm{NFI} \leq 1$. Sehingga, Goodness of Fit dalam penelitian ini dinyatakan lulus uji dan bisa dilanjutkan. 


\subsection{Uji Validitas dan Reliabilitas}

Setiap indikator dalam penelitian ini telah memenuhi syarat dari nilai Standardized Loading Factor $\geq 0.50$ dan nilai $\mathrm{t}$-value $\geq 1.96$. Maka, setiap indikator pada penelitian ini dapat dinyatakan valid. hasil penghitungan dari uji realibilitas variance extracted (VE) pada setiap variabel penelitian. Hasilnya menunjukkan bahwa hasil penghitungan GI, FV, dan PI telah memenuhi syarat yakni $C R \geq 0,7$ dan $V E \geq 0.50$. Maka, variabel pada penelitian ini dinyatakan reliable. Kemudian variabel IV dan SV tidak memenuhi syarat sehingga dinyatakan tidak reliable.

\subsection{Hasil Uji Hipotesis}

\begin{tabular}{|c|c|c|c|c|}
\hline Hipotesis & Pernyataan & Critical Value & Hasil $t$-value & Kesimpulan \\
\hline $\mathrm{H} 1$ & $\begin{array}{l}\text { Global Identity (GI) } \\
\text { berpengaruh positif terhadap } \\
\text { Purchase Intention (PI) }\end{array}$ & 1.65 & 5.27 & $\begin{array}{l}\text { Hipotesis H1 } \\
\text { diterima }\end{array}$ \\
\hline $\mathrm{H} 2$ & $\begin{array}{l}\text { Perceived Functional Value } \\
\text { (FV) berpengaruh positif } \\
\text { terhadap Purchase Intention } \\
\text { (PI) of consumer with Global } \\
\text { Identity (GI) }\end{array}$ & 1.65 & 3.40 & $\begin{array}{l}\text { Hipotesis H2 } \\
\text { diterima }\end{array}$ \\
\hline H3 & $\begin{array}{l}\text { Perceived Individual } \\
\text { Value (IV) berpengaruh } \\
\text { positif terhadap Purchase } \\
\text { Intention }(P I) \text { of consumer } \\
\text { with Global } \\
\text { Identity }(G I)\end{array}$ & 1.65 & -0.42 & $\begin{array}{l}\text { Hipotesis H3 } \\
\text { ditolak }\end{array}$ \\
\hline $\mathrm{H} 4$ & $\begin{array}{l}\text { Perceived Social Value } \\
(S V) \text { berpengaruh positif } \\
\text { terhadap Purchase } \\
\text { Intention (PI) of consumer } \\
\text { with Global } \\
\text { Identity }(G I)\end{array}$ & 1.65 & -0.18 & $\begin{array}{l}\text { Hipotesis H3 } \\
\text { ditolak }\end{array}$ \\
\hline
\end{tabular}

Sumber: data diolah dengan SEM

\subsection{Global identity memiliki pengaruh positif terhadap purchase intention of luxury product}

Beberapa penelitian sebelumnya yang mendukung seperti hasil penelitian Rusell and Rusell (2010) yang membuktikan bahwa nilai/ budaya global yang dianut 
oleh konsumen menjadi cikal bakal adanya keterikatan atau koneksi yang lebih luas dengan dunia global yang kemudian. Menciptakan identitas global customer. Begitupun dengan Strizhakova (2015) yang menambahkan bahwa customer dengan identitas global yang tinggi akan memiliki intensi yang lebih tinggi untuk membeli barang mewah dibandingkan barang lokal. Hal ini didasarkan pada fakta bahwa konsumen dengan identitas global yang tinggi memliki wawasan/ pengetahuan yang lebih terkait global market dan barang mewah. Sehingga melalui hasil penelitian ini, dapat diketahui pula bahwa konsumen dengan identitas global yang tinggi akan semakin tertarik atau memiliki keinginan yang tinggi dalam membeli produk mewah.

\subsection{Perceived functional value terhadap purchase intension of consumer with global identity}

Berdasarkan hasil uji hipotesis yang terlihat pada path diagram membuktikan bahwa variabel perceived functional value terbukti memiliki pengaruh negatif terhadap purchase intention of consumer with global identity karena nilai t-value yang lebih besar dari 1,65. Hasil ini sesuai dengan pernyataan hipotesis pada awal penelitian ini, dengan beberapa teori pendukung yang menyatakan bahwa barang mewah melekat pada image kualitas yang superior yang mengkomunikasikan nilai intrinsik yang lebih dibandiingkan produk lainnya (Bian and Forsythe, 2012) sehingga fungsional produk bukanlah faktor yang mendorong pembelian barang mewah (Park and Park, 2003).

Zhang and Cude (2018) dalam penelitiannya juga menambahkan kualitas merupakan faktor yang memiliki pengaruh signifikan terhadap pembelian barang mewah. Sehigga secara implemetasi, customer dengan identitas global yang tinggi tidak mempermasalahkan atau mempedulikan nilai fungsional ketika membeli barang mewah (Hennigs et al. 2012).

Dengan demikian melalui hasil penelitian ini, dapat diketahui pula bahwa konsumen dengan identitas global tertarik atau memiliki keinginan yang tinggi dalam membeli produk mewah tanpa mempertimbangkan sifat fungsional produk tersebut.

\subsection{Perceived individual value terhadap purchase intension of consumer with global identity}

Berdasarkan hasil uji hipotesis yang terlihat pada path diagram menyatakan bahwa hipotesis 3 ditolak karena nilai t-value lebih kecil daripada 1.65 atau dengan kata lain variabel perceived individual value tidak memiliki pengaruh positif terhadap purchase intention of consumer with global identity. Hasil ini sesuai dengan beberapa penelitian terdahulu (Yang and Mattila, 2016) yang membuktikan bahwa walaupun keinginan membeli barang/jasa mewah berkaitan erat dengan konsep diri, kepuasan, kebanggaan, dan reputasi diri, hal tersebut lantas tidak 
Secara otomatis menjadikan konsumen dengan identitas global yang tinggi memliliki purchase intention yang tinggi. Karena faktor lain seperti consumer attitude dan financial value juga merupakan hal penting dalam menentukan minat beli. Mengingat responden untuk penelitian ini adalah kaum milenial yang didominasi oleh usia pertengahan 20an, keinginan membeli barang mewah untuk sekedar kepuasan diri mungkin kurang sesuai dengan nilai-nilai yang dianut konsumen. Hal ini sejalan juga dengan penelitian Magetsari dan Pratomo (2019) yang membuktikan bahwa kebanggan dan identitas diri yang mencolok tidak cukup memunculkan minat beli yang tinggi bagi konsumen, apalagi terkat dengan konsumsi barang/jasa mewah.

\subsection{Perceived social value terhadap purchase intension of consumer with global identity}

Berdasarkan hasil uji hipotesis yang terlihat pada path diagram menyatakan bahwa hipotesis 4 ditolak karena nilai t-value lebih kecil daripada 1.65 atau dengan kata lain variabel perceived social value tidak memiliki pengaruh positif terhadap purchase intention of consumer with global identity. Hasil ini sesuai dengan penelitian terdahulu (Hung et al. 2011) yang membuktikan bahwa tidak ada pengaruh yang signifikan antara social value dan purchase intention. Faktor yang menyebabkan hal ini terjadi adalah kurangnya brand awareness yang dirasa konsumen terhadap produk mewah tersebut. Dalam hal ini konsumen merasa produk mewah tersebut belum dapat memenuhi kebutuhannya akan pengakuan sosial, dalam lingkup identitas global yang melekat pada konsumen tersebut.

\section{KESIMPULAN DAN SARAN}

\subsection{Kesimpulan}

Hasil analisa yang diperoleh dalam penelitian ini mengarahkan peneliti untuk menarik kesimpulan antara lain:

1. Global identity terbukti memiliki pengaruh positif dan signifikan terhadap purchase intention.

2. Perceived functional value memiliki pengaruh negatif dan signifikan terhadap purchase intention of consumer with global identity.

3. Perceived individual value tidak memiliki pengaruh positif terhadap purchase intention of consumer with global identity.

4. Perceived individual value tidak memiliki pengaruh positif terhadap purchase intention of consumer with global identity.

\subsection{Saran}

1. Saran bagi produsen Kain Tenun Ikat.

a. Pemasaran kain tenun ikat lebih digencarkan melaui berbagai platform media social, online shop, endorse oleh artis tanah air 
maupun mancanegara, serta secara langsung melalui promosi wisata di Flores.

b. Pemasaran kain tenun ikat juga perlu menonjolkan fungsi pakai dari kain tenun tersebut selain bahan untuk pakaian, seperti tas, dompet, kalung, belt, atau sebagai hiasan furniture dan asesoris lainnya.

c. Untuk meningkatkan awareness dan penjualan kain tenun ikat, produsen dapat menggunakan strategi penjualan berupa "customize", dimana produsen bebas mmproduksi barang sesuai dengan keinginan/ kebutuhan konsumen yang memesan, dengan menonjolkan corak kain tenun ikat.

\section{Saran bagi Pemerintah Daerah}

a. Promosi NTT sebagai tujuan wisata, sebaiknya dengan mengikutsertakan promosi kain tenun ikat di setiap sudut tempat wisata.

b. Memberdayakan tenaga produsen kain tenun ikat dengan berbagai pelatihan atau modal material yang menunjang produksi kain tenun itu sendiri.

c. Membuat suatu platform media sosial yang khusus untuk mempromosikan kain tenut ikat, memberikan info terkait kain tenun ikat dan meningkatkan awareness masyarakat luas terhadap kain tenun ikat NTT.

\section{Saran bagi Peneliti selanjutnya}

a. Untuk penelitian kedepannya kami mengusulkan untuk tambahkan kriteria sampel pada pertanyaan penyaring di dalam kuisioner online, yaitu "range tingkat pendapatan", yang dirasa memilki pengaruh besar terhadap pembelian produk mewah. Jadi, bila penelitian berikutnya ingin memakai kuisioner online sebaiknya pada setiap alat ukur dari setiap variabel di perhatikan supaya responden bisa mengerti maksud dari indikator yang diutarakan dan hasil yang didapati nantinya sesuai dengan kemauan yang ingin dicapai.

b. Penelitian selanjutnya memakai penelitian yang sama tapi sebaiknya bisa memilih objek yang berbeda dari penelitian yang telah dilakukan serta dengn cakupan sampel yang lebih luas dan merata, hal ini bertujuan untuk melihat atau bisa menjadi bahan perbandingan/refernsi untuk penelitian-penelitian selanjutnya serta apakah hasil pada objek yang berbeda memiliki perbedaan yang lebih baik. 


\section{DAFTAR PUSTAKA}

Amir, Firlie Lanovia. (2018, January). Pengembangan Kain Tenun Cepuk Sebagai Pendukung Daya Tarik Wisata Budaya Di Nusa Penida. Jurnal Master Pariwisata. Vol 4 No. 3, 327-339.

Arnett, Jeffrey Jensen. (2002, October). The Psychology of Globalization. American Psychologist. Vol. 57 No. 10, 774-78.

Banyte, Jurate dan Kazakeviciute, Asta. (2012). The Relationship of Consumers Perceived Hedonic Value and Behavior. Engineering Economics. Vol. 23 No. 5, 532- 540.

Berthon, Pierre et al. (2009). Aesthetics and Ephemerality: Observing and Preserving the Luxury Brand. California Management Review. Vol. 52 No. 1.

Bian, Qin dan Forsythe, Sandra. (2012, October). Purchase Intention For Luxury Brands: A Cross Cultural Comparison. Journal of Business Research. Vol. 65 No. $10,1443-1451$.

Gao et al. (2017, May). How Does Local-Global Identity Affect Price Sensitivity? Journal of Marketing. Vol. 81 No. 3, 62-79.

Hair et al (2010). Multivariate Data Analysis 7th Edition. Hair, Black, Babin, Anderson(1).pdf.

Hennigs et al. (2012, December). What is the value of luxury? A Cross-Cultural Consumer Perspective. Psychology and Marketing. Vol. 29 No. 12, 10181034.

Hsu, Chin-Lung dan Lin, Judy chuan-Chuan. (2015). What Drives Purchase Intention For Paid Mobile Apps? - An Expectation Confirmation Model With Perceived Value. Electronic Commerce Research and Appication. Vol. 14, 4657.

Hung et al. (2016). Antecedents of luxury brand purchase intention. Journal of Product \& Brand Management. Vol. 20, No.6, 457-467.

Jie Yang et al. (2018, January). Global Identity, Perceptions Of Luxury Value And Consumer Purchase Intention: Across-Cultural Examination. Jurnal of Consumer Marketing.

Li, Guoxin et al. (2012). Luxury Fashion Brand Consumers In China: Perceived Value, Fashion Lifestyle, And Willingness To Pay. Journal of Business Research. Vol. 65, 1516-1522. 
Liang et al. (2017). Chinese Consumers' Luxury Value Perceptions - A Conceptual Model. Qualitative Market Research: An International Journal. Vol. 20 No. 2, 247-262.

Magetsari, Ovy dan Pratomo, Luki. (2019, April). Faktor-faktor yang Mempengaruhi Purchase Intention Pada Luxury Restaurant. Jurnal Manajemen dan Kearifan Lokal Indonesia. Vol. 3, No. 1, 2019, pp. 25 - 41.

Nadek, Yorsi Florida dan Lutfiati, Dewi. (2018, May). Minat Konsumen Pada Tenun Ikat Ntt Di Sentra Tenun Ikat Ina Ndao Kota Kupang. Binus Business Review, Vol.7 No. 02, 100-105.

Naresh K. Malhotra. (2010). Marketing Research. Pearson.

Nelissen, Rob M.A. dan Meijers, Marijn H.C. (2011, September). Social Benefits Of Luxury Brands As Costly Signals Of Wealth And Status. Evolution and Human Behavior. Vol. 32 No. 5, 343-355.

Schindler, D. R. C. (2006). Marketing Research.

Shukla, Paurav. (2011, April). Impact Of Interpersonal Influences, Brand Origin And Brand Image On Luxury Purchase Intentions: Measuring Interfunctional Interactions And A Cross-National Comparison. Journal of World Business. Vol. 46 No. 2, 242-252.

Shuklaa, Paurav dan Purani, Keyoor. (2012, October). Comparing The Importance Of Luxury Value Perceptions In Cross-National Contexts. Journal of Business Research. Vol. 65 No. 10, 1417-1424.

Steenkamp, Jan-Benedict E.M. \& de Jong, Martijn G. (2010, November). A Global Investigation into the Constellation of Consumer Attitudes Toward Global and Local Products. Journal of Marketing. Vol. 74, 18-40.

Steenkamp, Jan-Benedict E.M. (2019). Global Versus Local Consumer Culture: Theory, Measurement, and Future Research Directions. Journal of International Marketing. Vol. 27 No. 1, 1-19.

Strizhakova, Yuliya dan Coulter, Robin A. (2015). Drivers of Local Relative to Global Brand Purchases: A Contingency Approach. Journal of International Marketing. Vol. 23 No. 1, 1-22.

Torelli et al. (2012, July). Brand Concepts as Representations of Human Values: Do Cultural Congruity and Compatibility. Journal of Marketing. Vol. 76, 92- 108.

Tu et al. (2012, March). A short 8-item scale for measuring counsumer's localglobal identity. International Jornal of Reesearch in Marketing. Vol. 29 No. 1, $35-42$. 
Tynan, Carolline et al. (2010). Co-creating value for luxury brands. Journal of Business Research. Vol 63, 1156-1163.

Werdhaningsih et al. 2014. Prakarya dan Kewirausahaan. Jakarta: Balitbang Kemendikbud.

Wang, Ying et al. (2011, July). Chinese Luxury Consumers: Motivation, Attitude and Behavior. Journal of Promotion Management. Vol. 17, No. 3, 345- 359.

Wiedmann et al. (2009, July). Value-Based Segmentation of Luxury Consumption Behavior. Psychology \& Marketing. Vol.26, No. 7, 625-651.

Wijanto, S. H. (2008). Structural equation modeling dengan Lisrel 8.8. Yogyakarta: Graha IImu.

Yang, Wan dan Mattila, Anna. (2016). "Why do we buy luxury experiences? Measuring value perceptions of luxury hospitality services". International Journal of Contemporary Hospitality Management, Vol. 28 Iss 9.

Zhang, Bopeng dan Kim, Jung-Hwan. (2013, January). Luxury Fashion Consumption In China: Factors Affecting Attitude And Purchase Intent. Journal of Retailing and Consumer Services. Vol. 20, No. 1, 68-79.

Zhang, Lini dan Zhao, Haidong. (2019, November). Personal Value Vs. Luxury Value: What Are Chinese Luxury Consumers Shopping For When Buying Luxury Fashion Goods? Journal of Retailing and Consumer Services. Vol. 51, 62-71.

Zhang, Yinlong dan Khare, Adwait. (2009, October). The Impact of Accessible Identities on the Evaluation of Global versus Local Products. Journal of Consumer Research. Vol. 36, No. 3, 524-537.

Makna Filosofis 14 Motif Tenun dari Nusa Tenggara.(2020, agustus 30). Retrieved from https://astinsoekanto.com/

Jumlah Wisatawan Domestik dan Mancanegara Provinsi NTT. (2016). Retrieved from https://ntt.bps.go.id

Contoh Motif Kain Tenun Ikat Flores - NTT Retrieved from https://venerandarantung.wordpress.com/

Data pertumbuhan PDB ekonomi kreatif di Indonesia (2016). Retrieved from https://www.bekraf.go.id 